\title{
THE IMPACT OF FINANCIAL LITERACY ON THE INVESTMENT DECISION OF NON-DONATION-BASED CROWDFUNDING IN INDONESIA
}

\author{
Jihan Nadra Arifah \\ Universitas Indonesia \\ Zuliani Dalimunthe* \\ Universitas Indonesia
}

\begin{abstract}
The present study investigates the heterogeneity of the financial literacy level between backers and nonbackers of non-donation-based crowdfunding in Indonesia and how the financial literacy relates to the country's decision to invest through non-donation crowdfunding. We choose Indonesia for a case study because non-donation crowdfunding has become a new investment mode recently in this area. The study extends the analysis to the predictors of financial literacy and its impact on the investment decision of nondonation crowdfunding. The hypotheses are examined through binary logistic regression. The study's findings are as follows. First, there is heterogeneity in the financial literacy level between backers and nonbackers. Second, the financial literacy level is found to be affected by residence, education, income, and stock market product ownership. Third, investors in crowdfunding have a tendency to be in the younger age group. Fourth, males have a higher tendency to invest in non-donation crowdfunding than females, despite the lack of difference in financial literacy between them. Fifth, individuals in the lowest income group are more likely to invest in non-donation crowdfunding than individuals with larger incomes.
\end{abstract}

Keywords: Non-Donation Crowdfunding; Financial Literacy; Crowdfunding Backers; Crowdfunding Investment Decision; Indonesia.

Received: 29 January 2019

Accepted: 12 June 2020

\section{INTRODUCTION}

Indonesia is predicted to be the country with the largest economy in Southeast Asia. Based on the research conducted by the International Monetary Fund (IMF) in 2016, Indonesia is ranked 8th in economic position, with a total gross domestic product (GDP) of US\$3.028 billion (Hawksworth, Audino, \& Clarry, 2017). In addition to its growth of GDP, the country's money supply has also increased, which indicates the increasing number of financial transactions for both personal and business needs.

Households' knowledge of financial planning should also be improved to keep pace with an increase in financial transactions. Whereas financial literacy is becoming increasingly important

\footnotetext{
- Corresponding author: Faculty of Economics and Business, Universitas Indonesia, 16424, Depok, Indonesia. Email: zuliani_d@ui.ac.id
} 
along with the development of financial products, the complexity of financial markets is also increasing as well as changes in political, demographic, and economic factors (Mouna \& Anis, 2017). Good financial literacy is believed to support efforts to achieve financial system stability, improve community welfare, and facilitate more inclusive development (Otoritas Jasa Keuangan, 2017).

However, the 2016 National Literacy and Financial Inclusion Survey (Survei Nasional Literasi Keuangan Indonesia, SNLKI) conducted by the Financial Services Authority (Otoritas Jasa Keuangan, OJK) shows that the level of financial literacy of Indonesian households regarding knowledge, skills, beliefs, attitudes, and behaviors is quite low, amounting to $29.66 \%$. When the level of financial literacy is grouped by sector, Figure 1 shows that the highest index of financial literacy of Indonesian households is in the banking sector, while the lowest is in the capital market sector.

Figure 1: Financial Literacy Indices of Financial Services Sectors in 2013 and 2016

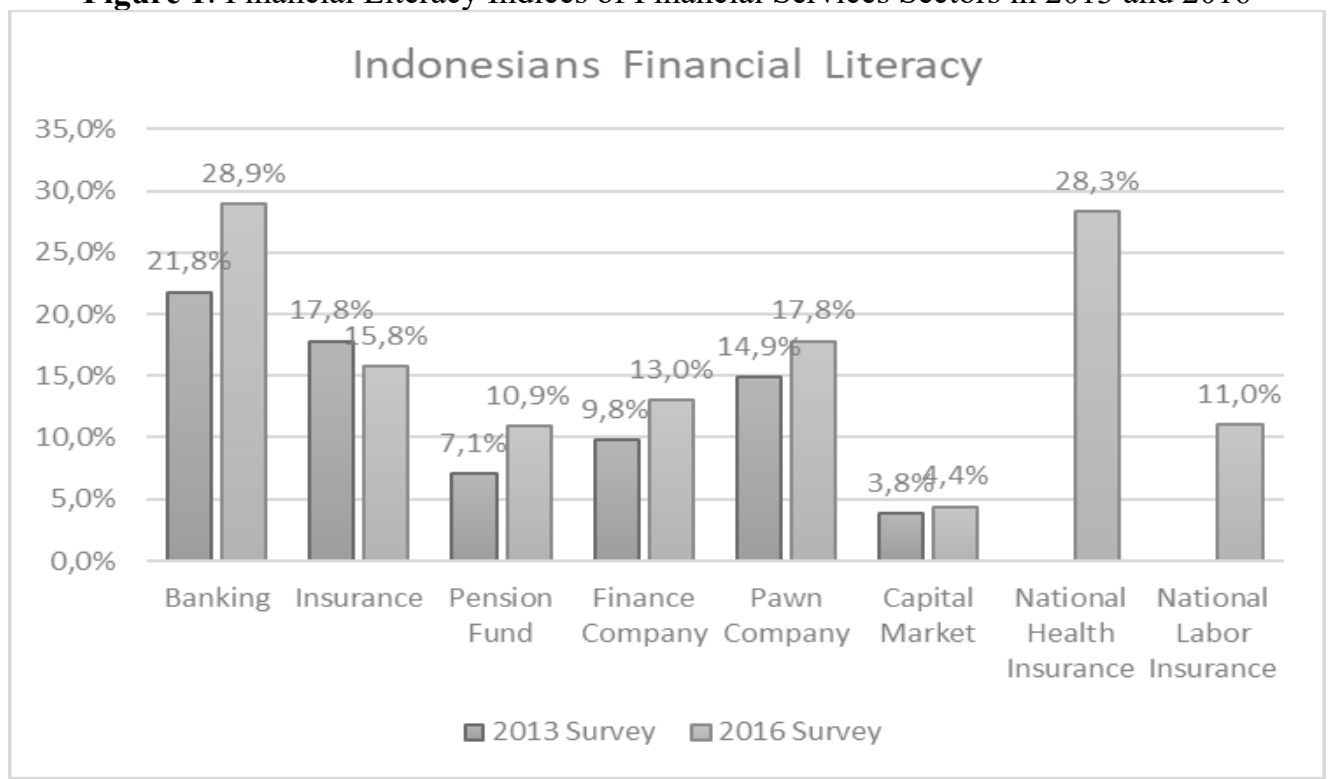

Source: National Survey on Indonesian Financial Literacy and Inclusion (2016)

At the same time, there has been rapid growth in information technology in recent years, especially regarding the use of Internet services. The survey conducted by the Indonesian Internet Service Providers Association (APJII, 2017) shows consistent growth in Internet users in Indonesia. By 2017, the number of Internet users in Indonesia reached 143.26 million people. This increase has had a positive impact on the growth of e-commerce transactions (Syakiela, Triono, \& Arif, 2019) and digital financial services (fintech). The report published by the Indonesian Fintech Association in 2016 showed that fintech products in Indonesia experienced rapid growth in the period of 2015-2016, as shown in Figure 2. The types of services offered vary, including payment transaction services, capital raising, investment management, and market 
provisioning. This growth impacts the ease of financial transactions that can be conducted anywhere and anytime.

Figure 2: Fintech Growth in Indonesia

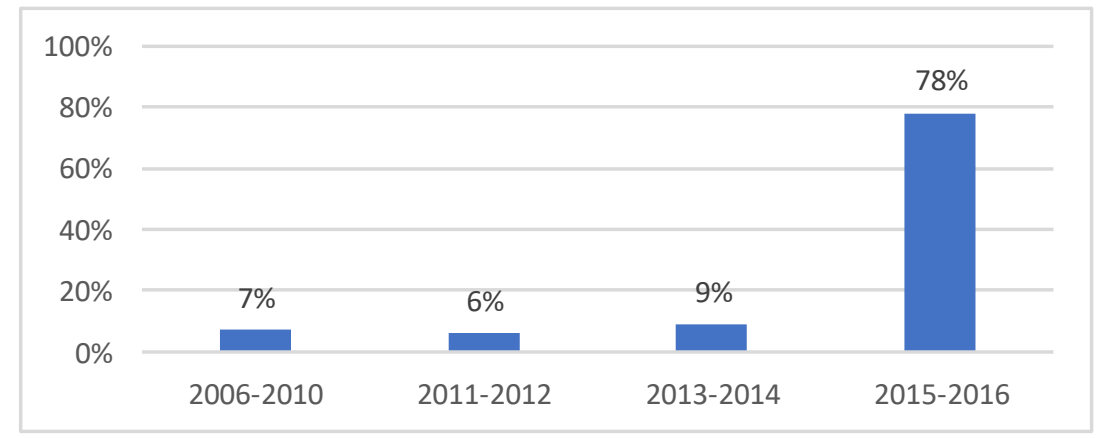

Source: Indonesia's Fintech Report in 2016

Donation crowdfunding has become common in Indonesia to finance a specific activity, such as relief for earthquake victims, floods, and forest fires or to improve the treatment of the poor who suffer from illnesses at high costs. Donation crowdfunding is generally broadcast through television or radio media to reach many people. The development of social media users causes crowdfunding activities to become increasingly easy and fast and to reach a wider community as other source for SME's equity financing in Indonesia. There are two major sources of equitybased financing exist in Indonesian market, venture capital firms and capital market. However, venture capital firms selectively put their investment on highly growth potential start-ups and tend to avoid small business (Macht \& Weatherston, 2014) while the capital market cannot be accessed by SME's (Dalimunthe, Syakhroza, Nasution, \& Husodo, 2019) Recently, crowdfunding activities in Indonesia have expanded to include non-donation forms. For example, kitabisa.com has developed an application for crowdfunding to finance business activities that generally involve small-scale businesses.

The development of non-donation crowdfunding in Indonesia raises the question of which nondonation crowdfunding activities the community aims to engage in. We suspect that this investment is mainly used as a process to learn about investing, because with a small amount of investment, the risk borne by the investor is also small. Individuals can learn the basics of financial concepts, primarily related to investment activities, through non-donation crowdfunding. Crowdfunding is a new investment tool with easy access to services and affordable funding. Investing in crowdfunding will gradually help people to understand the fundamentals of investing. Since the mechanism is simpler than that involved in investing in capital markets, it should increase individuals' financial literacy. Beginning with a simple product to understand, an individual can become involved in more sophisticated investment instruments such as stocks, mutual funds, and bonds.

This research aims to analyze the level of financial literacy of Indonesians by comparing the literacy levels between funders. Here we define funder as one who engages in investment or nondonation crowdfunding as a backer. We hypothesize that demographic factors (sex, age, domicile, 
education, and income) and ownership of capital market products affect a person's level of financial literacy and that financial literacy has a positive effect on investment decisions through non-donation crowdfunding.

The study is outlined as follows: Section 2 provides a literature review, Section 3 provides the research method, Section 4 presents the results followed by a discussion, and lastly, Section 5 provides the conclusion.

\section{LITERATURE REVIEW}

\subsection{Financial Literacy}

OECD (2011) defines financial literacy as:

"combination of awareness, knowledge, skill, attitude and behaviour necessary to make sound financial decisions and ultimately achieve individual financial wellbeing"

According to Otoritas Jasa Keuangan (2017), such knowledge and understanding is to make effective decisions in various financial contexts, improve the financial welfare of households, and enable participation in economic activity. Financial literacy provides substantial benefits, such as the ability to choose and utilize financial products and services, develop better financial planning skills, and avoid investment activities on disadvantageous financial instruments. Also, the use of financial products and services among households will be a source of funds to develop and strengthen the resilience of Indonesia's financial system when facing financial shocks.

Prior studies used various demographic factors to analyze financial literacy. Volpe, Kotel, and Chen (2002) examined the knowledge of 530 individuals investing online by exploring the differences in the level of financial literacy among different groups of respondents, with age, income, gender, education, and online trading experience as variables. They found that the level of financial literacy varied by education, experience, age, income, and gender; that females had a lower level of financial literacy than males; and that those in the older age group had more knowledge than those in the younger age group. Also, respondents with higher incomes had better investment knowledge than those who earn less. Similarly, respondents with a college education have more understanding than respondents who have less education. Lusardi and Mitchell (2011) found a positive influence of formal education on financial literacy. Then, Stolper and Walter (2017) summarize factors that influence financial literacy, including education, income and wealth, age, sex, occupation, and IQ.

There are also studies indicated the influence of financial literacy on participation in investing activities. Van Rooij, Lusardi, and Alessie (2011) stated that financial literacy influences financial decision making, as respondents with low literacy tend not to invest in the capital market. Frijns, Gilbert, and Tourani (2014) found a positive correlation between capital investment experience and financial literacy. Frijns et. al. (2014) also found that individuals with more financial expertise tend to be more willing to acquire further financial knowledge, both through financial education programs and self-education. Allgood and Walstad (2016) evaluate how financial literacy affect to financial behaviour on credit cards, investment, loans, insurance 
and financial advice. Mouna and Anis (2017) found that individuals with a low level of financial literacy are less likely to invest in the stock market.

\subsection{Financial Technology and Crowdfunding}

Fintech is a combination of financial services and technology, moderating a conventional business model and facilitating long-distance transactions within a short time. Romānova and Kudinska (2016) stated that fintech can be perceived as a form of integration between finance and technology in which the process from the new technology base will replace traditional financial structures. This certainly illuminates its important role in the field of financial services in Indonesia, where this business is a form of innovation in financial services that can provide convenience and effectiveness in dealing with financial products and services. The emergence of fintech in the era of industrial revolution 4.0 in Indonesia can provide a solution to the difficulty of generating loans from financial institutions. The Financial Services Authority (OJK) data showed that fintech financing experienced a significant increase in bad loans ratio, from $0.99 \%$ in December 2017 to $1.28 \%$ in January 2019.

The concept of crowdfunding comes from the broader concept of crowdsourcing, which involves using the "crowd" to obtain ideas, feedback, and solutions to develop corporate activities. Crowdsourcing takes place when a profit-oriented firm outsources specific tasks essential to the making or sale of its product to the public (the crowd) in the form of an open call over the Internet, with the intention of animating individuals to contribute to firms' production processes for free or for significantly less than that contribution is worth to the firm (Belleflamme, Lambert, and Schwienbacher, 2014).

Crowdfunding aims to raise money for funding, generally by using social networking. In other words, instead of collecting money from a small group of investors, crowdfunding helps companies or individuals raise funds from the crowd for business (Macht \& Weatherston, 2014) especially as early-stage project funding (Davies and Giovannetti, 2018). Such investments can be in the form of purchases of equity, loans, donations, or pre-orders products (Paschen, 2017). All crowdfunding activities require many funders to help entrepreneurs carry out specific activities or production.

Paschen (2017) outlines the typology of crowdfunding by considering the types of rewards offered to backers. They are (a) Donation Crowdfunding, in which the founder receives money from a crowd without any tangible return for that contribution, (b) Lending Crowdfunding, in which investors require payback of principal and interest payments, and (c) Equity Crowdfunding, in which the venture raises money from a crowd in exchange for an ownership stake in the firm or equity or bond-like shares. 


\section{METHODOLOGY}

\subsection{Hypothesis and Questionnaire Design}

Referring to the literature review above, the hypotheses to be analyzed for this research are categorized as follows:

A. Main hypothesis:

H(1): Financial literacy affects backers' decision to invest in non-donation crowdfunding.

B. Other hypotheses:

$\mathrm{H}(2)$ : demographic factors such as gender, age, domicile, education background, and income affect financial literacy.

$\mathrm{H}(3)$ : Demographic factors such as gender, age, domicile, education background, and income affect backers' decisions to invest in non-donation crowfunding.

$\mathrm{H}(4)$ : Capital market product ownership affects financial literacy.

$\mathrm{H}(5)$ : Capital market product ownership affects backers' decision to invest in nondonation crowfunding.

To measure financial literacy level, we replicated three questions known as The Big Three, developed by Lusardi and Mitchell (201). The first question related to the ability to count through the concept of interest, the second question related to inflation and money illusion, and the third question linked to the risk of diversification.

\subsection{Sample and Data Collection}

The sample of this study includes Indonesians, including both those who participate in nondonation crowdfunding (as backers) and those who do not. The samples collected in this study came from 252 respondents consisting of 126 respondents who commit to non-donation crowdfunding and 126 otherwise. The data were collected through questionnaires. Questionnaires were distributed from April 2018 to May 2018 using the Google Forms program. This method was utilized because of the ease of the process of dissemination and because it allows respondents to fill out surveys anywhere and anytime, with a vast area of dispersion.

\subsection{Models and Measurement of Variables}

The research model in this study consists of two models. The main model is the second model, used to analyse how financial literacy affects the decisions of the backers to invest in nondonation crowdfunding. The first model, applied during the pre-evaluation, uses variables that play the roles as controlling variables within the second model. We conducted regression for all respondents in the first model, while the second model only covered backers or investors in nondonation crowdfunding. The analysis was performed using binary logistic regression.

Model 1.

Finlit $=\alpha+\beta_{1}$ Gender $_{i}+\beta_{2}$ Age $_{i}+\beta_{3}$ Domicile $_{i}+\beta_{4}$ Edu $_{i}+\beta_{5}$ Income $_{i}+\beta_{6}$ Invder $_{i}+\varepsilon_{i}$ 
Model 2.

Backers $=\alpha+\beta_{1}$ Finlit $_{i}+\beta_{2}$ Gender $_{i}+\beta_{3}$ Age $_{i}+\beta_{4}$ Domicile $_{i}+\beta_{5}$ Edu $_{i}+\beta_{6}$ Income $_{i}+$ $\beta_{7}$ Invder $_{i}+\varepsilon \mathrm{i}$

Figure 3: Research Model (Model 2)

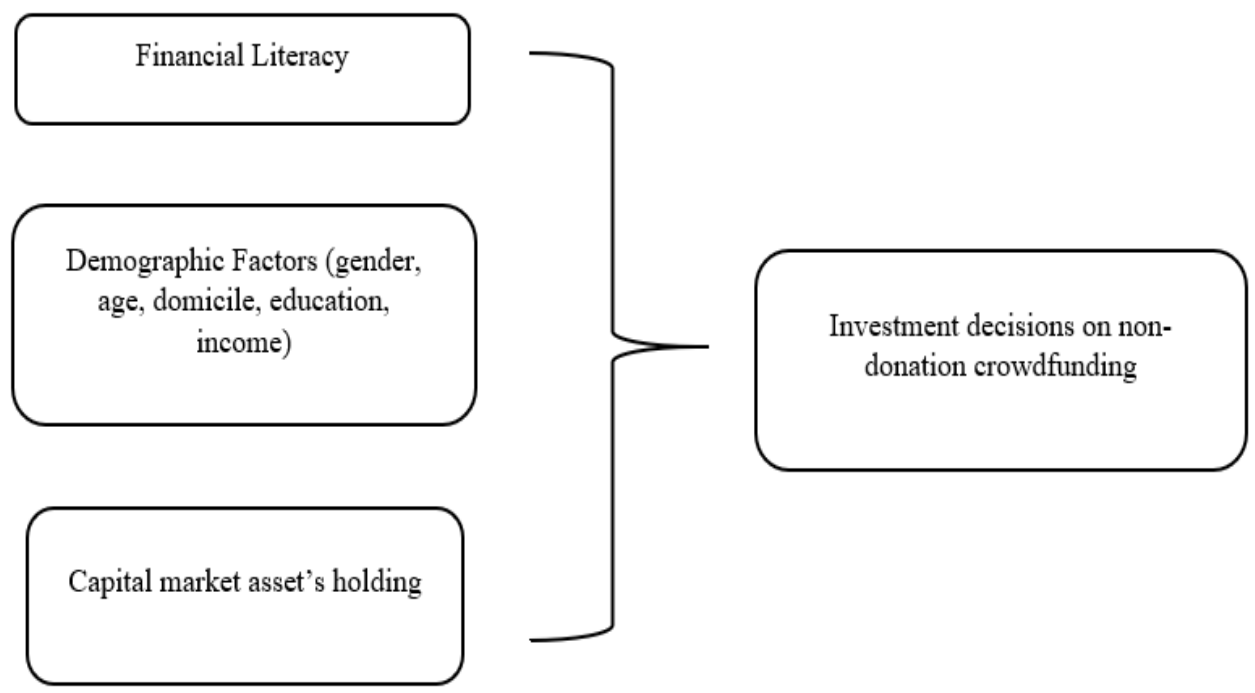

Table 1: Operational Definition of Variables

\begin{tabular}{|c|c|}
\hline Variable & Definition \\
\hline Finlit & $\begin{array}{l}\text { The Finlit is a dichotomous variable that takes a value of } 1 \text { if the financial literacy is } \\
\text { high and } 0 \text { if not }\end{array}$ \\
\hline Backers & Backers $=1$ if a respondent invests in non-donation crowdfunding, 0 otherwise \\
\hline Gender & Gender $=1$ if a respondent is male, 0 otherwise \\
\hline Age & $\begin{array}{l}\text { A categorical variable that takes a value of } 1,2,3 \text {, respectively, if the age group is (18- } \\
25),(26-35),(>36)\end{array}$ \\
\hline Domicile & Domicile $=1$ if a respondent lives in the Jabodetabek area, 0 otherwise \\
\hline Edu & $\begin{array}{l}\text { Edu }=1 \text { if a respondent's education level is university student } \\
\text { (diploma/undergraduate/postgraduate degree), } 0 \text { otherwise }\end{array}$ \\
\hline Income & $\begin{array}{l}\text { A categorical variable that takes a value of } 1,2,3,4,5 \text {, respectively, if the income } \\
\text { group is (IDR) }(<1-2 \mathrm{~m}),(2-4 \mathrm{~m}),(4-6 \mathrm{~m}),(6-8 \mathrm{~m}),(>8 \mathrm{~m})\end{array}$ \\
\hline Invder & Invder $=1$ if the respondent holds at least one capital market product, 0 otherwise \\
\hline
\end{tabular}




\section{RESULTS AND DISCUSSION}

\subsection{Results}

The following tables provide the financial literacy level of respondents and the regression results.

Table 2: Financial Literacy Level

\begin{tabular}{lcccc}
\hline \hline & Low literacy & High literacy & Total & Mean \\
\hline Backers & 23 & 103 & 126 & 2.4 \\
Non-Backers & 75 & 51 & 126 & 1.3 \\
Overall Score & 98 & 154 & 252 & 1.8 \\
\hline \hline
\end{tabular}

Table 2 shows the difference in the average financial literacy based on the total score obtained from the respondents. Each correct answer was scored as 1, while false or "do not know" answers scored 0 . From the table above, we conclude that the financial literacy of Indonesians is quite low. If the average score is grouped based on investment activity (invest=backers/not invest=nonbackers), the average score of respondents is 2.4 . These results suggest that respondents who are investors of crowdfunding non-donations (backers) have good financial literacy. The average score of non-investors (non-backer) respondents is 1.3 , indicating low financial literacy. We conducted a means test for the financial literacy variable between backers (investors) and nonbackers. The t-value of 7.761 with a p-value (2-tailed) of 0.000 indicates that there are significant financial literacy differences between backers and non-backers. Thus, we examine further how certain backers' characteristics relate to their decision to invest in non-donation crowdfunding.

Table 3 shows the result of the logistic regression that examined the determinants of financial literacy. It demonstrated that residential area, education, income level, and capital market ownership significantly affect financial literacy. Meanwhile, there is no evidence that gender and age affect financial literacy.

Table 3: Logistic Regression Results on Determinants of Financial Literacy

\begin{tabular}{lccc}
\hline \multicolumn{1}{c}{ Variables } & p-value & Coefficient (B) & $\begin{array}{c}\text { Odds ratio } \\
\text { (Exp(B)) }\end{array}$ \\
\hline Gender: Male & 0.224 & 0.469 & 1.598 \\
\hline Age (Base group: 18-25 years) & & & \\
$\quad$ 26-35 years & 0.104 & 0.688 & 1.990 \\
$\quad$ More than 36 years & 0.792 & -0.269 & 0.764 \\
\hline Residential: Jabodetabek & $0.015^{*}$ & 0.858 & 2.360 \\
\hline Education: University student & $0.000^{*}$ & $3, .783$ & 43.95 \\
\hline Income (Base group: <IDR1-2m) & & & \\
$\quad$ IDR2,000,100-4,000,000 & 0.180 & -0.600 & 0.549 \\
$\quad$ IDR4,000,100-6,000,000 & $0.085^{* *}$ & $0, .856$ & 2.353 \\
$\quad$ IDR6,000,100-8,000,000 & $0.049^{*}$ & $1, .373$ & 3.947 \\
$\quad$ >IDR8,000,100 & 0.368 & 0.565 & 1.760 \\
\hline Capital market product's ownership: Holds & $0.006^{*}$ & 1.259 & 3.523 \\
at least 1 product & 0.000 & -4.547 & 0.011 \\
\hline Constanta & & & \\
\hline \hline
\end{tabular}

Notes: *sig at the $5 \%$ level, $* *$ sig at the $10 \%$ level 
Table 4: Logistic Regression Results on Variables Impact to Investing Decision

\begin{tabular}{|c|c|c|c|}
\hline Variables & p-value & Coeff. (B) & $\begin{array}{c}\text { Odds ratio } \\
(\operatorname{Exp}(B))\end{array}$ \\
\hline Financial literacy: High literacy & $0.000^{*}$ & 1.424 & 4.154 \\
\hline Gender: Male & $0.008^{*}$ & 0.921 & 2.513 \\
\hline \multicolumn{4}{|l|}{ Age (Base group: $18-25$ years) } \\
\hline $26-35$ years & 0.749 & 0.122 & 1.130 \\
\hline More than 36 years & $0.086^{* *}$ & -1.704 & 0.182 \\
\hline Residential: Jabodetabek & 0.196 & -0.454 & 0.635 \\
\hline Education: University student & 0.675 & -0.230 & 0.794 \\
\hline \multicolumn{4}{|l|}{ Income (Base group: $<$ IDR1-2mn) } \\
\hline IDR2, $000,100-4,000,000$ & $0.002 *$ & -1.530 & 0.217 \\
\hline IDR $4,000,100-6,000,000$ & $0.085^{* *}$ & -0.829 & 0.436 \\
\hline IDR6,000,100-8,000,000 & $0.032 *$ & -1.237 & 0.290 \\
\hline$>$ IDR $8,000,100$ & 0.454 & 0.474 & 1.606 \\
\hline $\begin{array}{l}\text { Capital market product's ownersl } \\
\text { at least } 1 \text { product }\end{array}$ & $0.000 *$ & 1.473 & 4.364 \\
\hline Constanta & 0.291 & -0.571 & 0.565 \\
\hline
\end{tabular}

Notes: ${ }^{*}$ sig at the $5 \%$ level, ${ }^{* *}$ sig at the $10 \%$ level

Table 4 showed the result of logistic regression about how an investor with specific characteristics is likely to invest in non-donation crowdfunding (backers). The Nagelkerke $\mathrm{R}$ Square model is $49.3 \%$, indicating the ability of the model to explain investment decisions in non-donation crowdfunding in Indonesia. From Table 4, we found that financial literacy, gender, age, income, and capital market ownership significantly affect the tendency to invest in nondonation crowdfunding.

\subsection{Discussion}

Among the three financial concepts applied to assess the level of financial literacy, the most familiar is the concept of interest. Out of 252 respondents, 106 (67.1 percent) answered the concept of interest correctly. This result might be due to the application of interest in the most commonly used financial products, such as in savings and credit, so that people are more familiar with the subject and can answer adequately. This finding is in line with the SNLKI result held by Otoritas Jasa Keuangan (2017), in which the household's understanding of the concept of interest is better than inflation. The most unfamiliar concept for respondents is the concept of diversification, to which 141 respondents answered correctly. This conclusion might be due to the amount of non-investor respondents among the overall respondents that might be not familiar with investment activity and the importance of diversifying to minimize risks to investment.

Table 3 shows that residential area, education, income level, and capital market ownership significantly affect financial literacy. Individuals domiciled in the Jabodetabek area demonstrate 2.360 times greater financial literacy than those living outside Jabodetabek. This might be due to the uneven regional development regarding available resources, livelihood, location, accessibility, and population growth. This finding is in line with the provincial financial literacy index released by Otoritas Jasa Keuangan (2017), indicating that the provinces in Java Island tend to have a financial literacy index above the national average score, which is in contrast to those in regions outside Java. Education variables also significantly influence financial literacy, as individuals 
with university education backgrounds are 43,950 times more likely to have high financial literacy than individuals who do not have university education backgrounds. The value of education background in this case might differ from previous research, but this finding is in line with research conducted by Volpe, et.al. (2002); Van Rooij, et. al. (2011); and Mouna and Anis (2017), who found that the higher a person's education level, the higher the tendency he or she has for better financial literacy.

Also, some categories of income variables significantly influence financial literacy. This finding is in line with the research conducted by Volpe, et.al, (2002), Calvet, Campbell, and Sodini (2009); and Lusardi and Mitchell (2011). Income categories in Indonesia that have a significant effect include groups with income ranges from IDR4,000,100 to IDR6,000,000 and classes of IDR6,000,100 to IDR8,000,000, and the individuals involved in either of these two categories are 2.353 times and 3.947 times more likely to have better financial literacy, respectively, than those with lower incomes.

Finally, in addition to the demographic factors, this study also applied the variable of capital market ownership during the analysis. Regression results showed a significant influence on financial literacy. Individuals who own capital market products are 3.523 times more likely to have better financial literacy than individuals who do not have a capital market product. This finding is in line with the research of Frijns, et.al., (2014), which shows a positive relationship between capital market experience and financial literacy.

Table 4 showed the result of logistic regression regarding how variables impact investment decisions. It proved that financial literacy, gender, age, income, and capital market ownership significantly affect the investment decision of individuals engaging in non-donation crowdfunding. The test results confirm that financial literacy has a significant effect on the investment decision of non-donation crowdfunding. Individuals who have high financial literacy have a 4.154 times greater probability of participating in non-donated crowdfunding than individuals with low financial literacy. This result confirms the findings that individuals with poor financial literacy tend to avoid investing (Van Rooij, et.al., 2011). This tendency might be due to a lack of confidence in their ability to invest due to unfamiliarity with the concepts related to investing.

Regarding demographic factors, we found that the probability of males to invest in non-donated crowdfunding is 2.513 times higher than that of females. This finding is in line with Anis and Mouna (2017) and Hsiao and Tsai (2018), who found that males have a greater tendency to participate in the capital market than females. Moreover, some categories in the age variable are proven to have a significant effect on the crowdfunding investment decision. We found that the tendency of the participants older than 36 years to invest in non-donation crowdfunding is only 0.182 times the rate of those in the group aged 18-25 years. This finding might be because the non-donation crowdfunding here is a financial product whose overall activity relies on the Internet. Quoting from SNLKI of Otoritas Jasa Keuangan (2017) regarding age, most Internet users in Indonesia are in the age range of 25-34 years (75.8\%), followed by users aged 10-24 years $(75.5 \%)$. We then found that the residential factor does not affect the likelihood to participate in non-donation crowdfunding, whether a person lives in the Jabodetabek area (capital city and the neighboring city) or outside Jabodetabek. However, the variable of capital market ownership has a significant effect on the funding decision regarding non-donation crowdfunding. 
Individuals who own capital market products tend to be 4.364 times more likely to invest in nondonated crowdfunding than individuals who do not have capital market products.

Regarding income level variables, we found impressive results. In contrast to previous research, individuals of the lowest income group were more likely to invest than individuals with more substantial incomes. Those of income levels of IDR2,000,100 to IDR4,000,000 tend to be 0.217 times less likely to participate in non-donation crowdfunding than the lowest income group or equivalent to less than IDR1,000,000 to IDR2,000,000. Similarly, the group with incomes of IDR4,000,100 to IDR6,000,000 tend to be 0.436 times less likely to participate in crowdfunding than the group with the lowest income. The same trend direction was also shown in the group with incomes of IDR6,000,100 to IDR8,000,000, which tend to be 0.290 times less likely to invest than the smallest income group. These findings may arise because crowdfunding is perceived as an attractive option for those of the lowest income group due to a minimum capital amount needed to start the investment, beginning from IDR10,000 to IDR100.000.

\section{CONCLUSION}

The main result of this study shows that financial literacy significantly differentiates the likelihood of an Indonesian to invest through non-donation crowdfunding. Even though the overall financial literacy of Indonesians is quite low, the group of investors (backers) demonstrated better financial literacy than those who non-backers. Furthermore, individuals who have high financial literacy have a 4.154 times greater probability to invest than individuals with low financial literacy. We also found that individuals domiciled in the Jabodetabek area (the capital city and neighboring areas) show a financial literacy rate 2.360 times greater than those living outside Jabodetabek, even though domicile factors do not differentiate the likelihood to invest in non-donation crowdfunding. Regarding the education factor, we found that individuals with university education backgrounds tend to be 43,950 times more likely to have better financial literacy than individuals who do not have university education backgrounds. This finding is surprising, but the direction is in line with the findings from previous research that individuals with university backgrounds tend to invest in non-donation crowdfunding.

Furthermore, there are two interesting findings in this research. First, despite the lack of difference in financial literacy between males and females, we found that males are 2.513 times more likely to invest in non-donated crowdfunding than females. Second, individuals in the lowest income group were more likely to invest in non-donation crowdfunding than individuals with higher incomes. This finding could indicate that equity crowdfunding plays a role for lowerincome group individuals as an investing learning tool before they make a more significant investment. We suggest that regulator to utilize crowdfunding activities to design financial education programs effectively and efficiently to increase the financial literacy of Indonesians.

However, we need future research to confirm this hypothesis. Also, we recognize that the number of respondents in this research is not enough to represent all Indonesians, since this research included respondents in the area inside and outside Jabodetabek. Because non-donation crowdfunding is a new phenomenon with fewer participants, obtaining large numbers of respondents is not easy. In the future, research in this field could involve broader groups of respondents to draw more reliable conclusions. 


\section{ACKNOWLEDGEMENT}

We want to thank Universitas Indonesia, through the PITTA 2018 Program, which financed the project.

\section{REFERENCES}

Allgood, S., \& Walstad, W. B. (2016). The effects of perceived and actual financial literacy on financial behaviors. Economic Inquiry, 54(1), 675-697.

Indonesian Internet Service Providers Association (APJII) (2017). Infografis penetrasi dan perilaku pengguna internet Indonesia. Retrieved from https:/apjii.or.id/content/ $\mathrm{read} / 39 / 342 /$ Hasil-Survei-Penetrasi-dan-Perilaku-Pengguna-Internet-Indonesia-2017

Belleflamme, P., Lambert, T., \& Schwienbacher, A. (2014). Crowdfunding: Tapping the right crowd. Journal of business venturing, 29(5), 585-609.

Calvet, L. E., Campbell, J. Y., \& Sodini, P. (2009). Measuring the financial sophistication of households. In American Economic Review, 99, 393-398.

Dalimunthe, Z., Syakhroza, A., Nasution, M. E., \& Husodo, Z. A. (2019). How Feasible a Convertible Ijarah Contract for SME's Financing: A Simulation Approach. Journal of Islamic Monetary Economics and Finance, 5(2), 439-458.

Davies, W. E., \& Giovannetti, E. (2018). Signalling experience \& reciprocity to temper asymmetric information in crowdfunding evidence from 10,000 projects. Technological Forecasting and Social Change, 133, 118-131.

Frijns, B., Gilbert, A., \& Tourani-Rad, A. (2014). Learning by doing: the role of financial experience in financial literacy. Journal of Public Policy, 34(1), 123-154.

Hawksworth, J., Audino, H., \& Clarry, R. (2017). The Long View-How will the global economic order change by 2050?. Report by PWC. Retrieve from https://www.pwc.com

Hsiao, Y. J. \& Tsai, W. C. (2018). Financial literacy and participation in the derivatives markets. Journal of Banking \& Finance, 88, 15-29.

Lusardi, A., \& Mitchell, O. S. (2011). Financial literacy around the world: An overview. Journal of Pension Economics and Finance, 10(4), 497-508.

Macht, S. A., \& Weatherston, J. (2014). The benefits of online crowdfunding for fund-seeking business ventures. Strategic Change, 23(1-2), 1-14.

Mouna, A., \& Anis, J. (2017). Financial literacy in Tunisia: Its determinants and its implications on investment behavior. Research in International Business and Finance, 39, 568-577.

Organisation for Economic Co-operation and Development (OECD) (2011). Measuring Financial Literacy: Core Questionnaire in Measuring Financial Literacy: Questionnaire and Guidance Notes for conducting an Internationally Comparable Survey of Financial literacy. Retrieved from https:/www.oecd.org/finance/financial-education/49319977.pdf

Otoritas Jasa Keuangan (2017). Strategi Nasional Literasi dan Inklusi Keuangan Indonesia (Revisit 2017). Retrieved April 10, 2018 from https://www.ojk.go.id

Paschen, J. (2017). Choose wisely: Crowdfunding through the stages of the startup life cycle. Business Horizons, 60(2), 179-188.

Romānova, I., \& Kudinska, M. (2016). Banking and Fintech: A Challenge or Opportunity? Contemporary Issues in Finance: Current Challenges from Across Europe, 98, 21-35.

Stolper, O. A., \& Walter, A. (2017). Financial literacy, financial advice, and financial behavior. Journal of Business Economics, 87(5), 581-643. 
Syakiela, N., Triono, R. A., \& Arif, H. (2019). Electronic WOM effectiveness from online social network perspectives in Indonesia. In Soliman, K. S (Eds), Proceedings of the 33rd International Business Information Management Association Conference, IBIMA 2019: Education Excellence and Innovation Management through Vision 2020 (pp. 6406-6422). Granada, Spain.

Van Rooij, M., Lusardi, A., \& Alessie, R. (2011). Financial literacy and stock market participation. Journal of Financial Economics, 101(2), 449-472.

Volpe, R. P., Kotel, J. E., \& Chen, H. (2002). A survey of investment literacy among online investors. Journal of Financial Counseling and Planning, 13(1), 1-13. 